\title{
Response of Different Grafted Eggplants in Protected Culture
}

\author{
Gheorghita $\mathrm{HOZA}^{1 *}$, Mădălina DOLTU², Maria DINU³ \\ Alexandra D. BECHERESCU ${ }^{4}$, Alexandru I. APAHIDEAN ${ }^{5}$, \\ Marian I. BOGOESCU ${ }^{2}$
}

\author{
${ }^{1}$ University of Agronomic Sciences and Veterinary Medicine, Faculty of Horticulture Bucharest, 59 Marasti Street, Bucharest, \\ Romania; hozagh@yahoo.com (*correspondingauthor) \\ ${ }^{2}$ Research and Development Institute for Industrialization and Marketing of Horticultural Products "Horting", 5 N Drumul Gilăului Street, \\ Sector4,041715Bucharest,Romania; bogoescu@yahoo.com;doltu_mada@yahoo.com \\ ${ }^{3}$ University of Craiova, 13 Alexandru Ioan Cuza Street, Craiova, Romania; dinumariana@hotmail.com \\ ${ }^{4}$ Banat University of Agricultural Sciences and Veterinary Medicine Timisoara, 119 Calea Aradului Street, Timisoara, \\ Romania; alexandra_becherescu@yahoo.com \\ ${ }^{5}$ University of Agricultural Sciences and Veterinary Medicine Cluj-Napoca, 3-5 Manastur Street, Cluj-Napoca, \\ Romania; alexandru.apabidean@usamvcluj.ro
}

\begin{abstract}
The study has been conducted in a professional greenhouse where grafted seedlings and grafted eggplants have been produced. Two eggplant hybrids, 'Classic F1' and 'Black Pear F1' were used as scion and one of the Lycopersicon genus, 'Kaiser F1' and three Solanum genus, 'L1S', 'L23B' and 'Torpedo' were used as rootstocks, resulting in eight grafted combinations. It has been observed that for all grafting combinations the grafting percentage was ranging from $95 \%$ to $98 \%$. The rootstocks utilized have influenced the vigour of the grafted plants. They influenced plant height which reached values of roughly $1.0 \mathrm{~m}$ and number of leaves resulting in values of 2.5-3.0 times higher in comparison to the ungrafted plants. Comparative to the ungrafted plants the grafting combinations also influenced the productivity of plants. The highest fructification potential has been observed at 'Classic F1' grafted on all eggplant rootstocks. Compared to ungrafted plants, which has yielded $2.46 \mathrm{~kg}$ per plant, the highest yield obtained from 'Classic F1' grafted on 'L23B' has been of $4.27 \mathrm{~kg}$ per plant, followed by 'Torpedo' rootstock with $4.1 \mathrm{~kg}$ per plant. 'Black Pearl F1' have been produced $4.15 \mathrm{~kg}$ per plant when grafted on the 'Kaiser F1' rootstock and $4 \mathrm{~kg}$ per plant when grafted on the 'Torpedo' rootstock. Regarding the production per hectare, the largest production augmentation, of 30\%, was noted at 'Classic F1' grafted on the eggplant rootstock 'L23B'. The 'Black Pearl F1' grafted on the tomato rootstock 'Kaiser F1' registered a 20\% increment in production. The rootstocks utilized have slightly influenced the content of the soluble dry substance on both hybrids grafted on 'Kaiser F1'. The result has been a $6 \%$ dry substance in comparison to the $5.3 \%$ at the ungrafted hybrids. The grafting has had an insignificant influence of the total amount of carbohydrates at all grafting combinations.
\end{abstract}

Keywords: greenhouse, production, rootstock, scion, seedlings

\section{Introduction}

Plant grafting has been practiced for more than 2000 years (Haroldsen et al., 2012). However, vegetables grafting is a much more recent practice which has been introduced in Europe at the end of the 20th century. From Europe it has been introduced in North America and over the last 50 years in East Asia as well, with grafting methods being continuously improved. Nowadays both conventional and organic vegetable gardeners are showing high interest for use of grafted plants (Kubota, 2008). Vegetable grafting is an alternative method to soil fumigation with methyl bromide (Echevarria, 2004; Miguel et al., 2004; Yetisir et al., 2003, 2007; Bogoescu et al., 2010) which has been banned according to the Montreal Protocol on Substances because of its negative impact on the ozone layer. Since 2005 Romania, as a signatory to this agreement, has prohibited the use of methyl bromide for soil disinfection by the Law 159/2000 (Bogoescu and Doltu, 2014).

Vegetable grafting is aimed to produce plants with higher resistance to soil diseases and pests but also to stress caused by abiotic factors. For tomatoes and eggplants it can be the technological solution for solving disease and pest 
474

problems (Leonardi and Giuffrida, 2006). Eggplants have a greater susceptibility to diseases and pests, especially to Fusarium, Verticillium and nematodes (Elekcioglu et al., 1994; Collonnier et al., 2001), causing yield loss of up to $78 \%$ in infested areas (Blestos et al., 2003). Eggplant production decreases significantly at the Verticillium attack, but the use of resistant rootstocks is an effective method of control upon this disease (Na Liu et al., 2009). Grafted seedlings have higher productivity and resistance to soil diseases (Fusarium spp., Verticillium spp.) and pests (nematodes) (Tarchoun et al 2005; Bogoescu et al., 2008). King et al. (2010) and Lee (1994) appreciated that grafting gives resistance to pathogens, soil pests, tolerance to abiotic stress, improves the absorption of water and nutrients and increases scion vigour. Blestos and Olympios (2008) showed that grafting on Solanaceae is an approach to reduce the incidence of disease and pest attack, similar to crop rotation.

Petran (2013) has noticed that tomatoes are compatible with Solanum torvun rootstocks obtained from seeds for which the survival percentage has been of $80-100 \%$. Comparatively, the rootstocks obtained from cuttings showed a percentage of only $50 \%$. The survival rate of grafted eggplants also depends on the environmental conditions. Thus, Johnson and Miles (2011) obtained an average survival rate for grafted eggplants of $82 \%$. However the value has dropped from $90 \%$ to $60 \%$ when relative humidity has also decreased which proves that eggplants need a high relative humidity (98\%).

Similar values of the stem diameters of scion and of rootstock are essential to obtain a high grafting percentage (McAvoy, 2005; Bogoescu et al., 2009; Doltu et al., 2013). It ensures close contact between the two plant fragments (Assenza, 2004) and vascular continuity through the two of them (Yassin and Hussen, 2015). The growth rate of scions and rootstocks seedlings can be different. Therefore, different dates are recommended for the seeding of rootstocks and scions. Bogoescu et al. (2013) has observed that the rootstock 'Emperador' (genus Lycopersicon) needs to be seeded 5 days after the seeding of eggplant scion cultivars ('Aragon' and 'Luiza') and the 'Torvum vigor' rootstock (genus Solanum) 20 days before seeding the scion.

The results regarding fruit quality of grafted plants and yield value are controversial as it has been proved by several authors (Davis et al., 2008; Moncada et al., 2013). Bogoescu and Doltu (2015) have showed that the carbohydrate content (2.54-2.97\%) at ungrafted eggplants has been higher in comparison to the grafted plants cultivated under the same technological conditions (1.92-2.00\%). Romano and Paratore (2001) have showed that grafting impacts slightly the characteristics of fruits. The most popular rootstocks for eggplants are tomatoes (Ioannou, 2001) and the wild species Solanum torvum Sw., Solanum integrifolium Poir. and Solanum sisymbriifolium Lam. (Lee, 1994; Blestos et al., 2003). Vigorous eggplant of wild relatives and interspecific hybrids are increasingly used for eggplant (Kaushik et al., 2016). However, there are few results on the effect of Solanum rootstock and grafted eggplants yield and quality of fruit on uninfected soils (Çürük et al., 2005) and for Verticillium infected soils (Blestos et al., 2003; Çürük et al., 2009).
Eggplants cultivation in Romania is important for vegetable gardeners and consumers and thus the soil infestation with diseases and pests can produce significant prejudice. One of the solutions of loss reduction is the use of grafted seedlings on resistant rootstocks. The present study has been aimed to obtain grafting combinations of eggplant rootstocks and cuttings from the Solanum and Lycopersicon genus and to test them in culture in order to observe their growth and fructification in comparison to the ungrafted plants. The present paper asserts the results of the comparative study between grafted plants on several rootstocks and ungrafted plants.

\section{Materials and Methods}

\section{Biologicalmaterial}

The study has been conducted between 2015 and 2016 at the Horting Institute Bucharest, Romania. The research involved two stages as it follows: the first phase consisted of producing grafted eggplant seedlings by using specific technology of vegetable grafting and the second phase consisted of comparing the grafted seedlings in a Venlo greenhouse in order to observe the growth and the production of plants.

The biological material used was represented by two eggplant hybrids, the 'Classic F1' and the 'Black Pearl F1', which were the scions and four rootstocks, one of the tomato genus, 'Kaiser F1' and three of eggplant, 'Torpedo', respectively 'L1S' and 'K23B' (two selections, obtained by VRDS Buzau Romania).

The study has been implemented in a randomized complete block design with four grafting combinations and the ungrafted control for each hybrid used. At every combination and at control 90 plants were used in 3 replications of 30 plants each resulting in the following experimental scheme, respectively variants: V1 - 'Classic F1' $\times$ 'L1S'; V2 - 'Classic F1' × 'Kaiser F1'; V3 - 'Classic F1' × 'L23B'; V4 - 'Classic F1' × 'Torpedo'; V5 - 'Classic F1' control (ungrafted); V6 - 'Black Pearl F1' × 'L1S'; V7 'Black Pearl F1' × 'Kaiser F1'; V8 - 'Black Pearl F1' $\times$ 'L23B'; V9 - 'Black Pearl F1' × 'Torpedo'; V10 - 'Black Pearl F1' control (ungrafted).

'Classic F1' has oval shaped fruits, dark indigo in color, with an up to $1.5 \mathrm{~kg}$ in weight and a length of $15 \mathrm{~cm}$. The plant is vigorous, average in size and well adapted to field conditions and protected areas. The vegetation time is of 75 days.

'Black Pearl F1' has semi-long fruits, dark indigo in color, shiny, firm, homogenous and transport resistant. It is a productive hybrid, with a compact habitus, highly recommended for field culture and protected areas.

'Torpedo' is an eggplant rootstock very vigorous which is highly compatible with grafting and very resistant to the nematodes Fusarium and Verticillium.

'Kaiser F1' is a tomato rootstock very vigorous which impacts the grafted plant with a harmonious growth. It is recommended for protected areas. Is it very resistant to the attack of the nematodes Fusarium sp., Verticillium, Wilt and ToMV.

'L1S' and 'L23B' are eggplant hybrids from the Solanum melongena species obtained at VRDS Buzau, Romania 
(Vegetable Research-Development Station) and are being tested as rootstocks at Horting Bucharest. They are homogenous, have genetic stability and high tolerance for the diseases and pests present in soil (Vînătoru et al., 2013).

\section{Producing grafted seedlings}

The seedlings have been produced in a $1450 \mathrm{~m}^{2}$ professional greenhouse covered with a double plastic film with underpressure air filling and equipped with heating, ventilation, shading and cooling systems.

The scions and rootstocks has been made in 70 alveolar plates with a capacity of $50 \mathrm{ml}$ per alveolus, using as substrate a peat with a grain size of $0-10 \mathrm{~mm}, 1 \mathrm{~kg} \mathrm{~m}^{-3}$ content in NPK, microelements $\mathrm{B}, \mathrm{Mg}, \mathrm{Cu}, \mathrm{Mn}, \mathrm{Zn}, \mathrm{Fe}$ and $\mathrm{S}\left(0.050 \mathrm{~kg} \mathrm{~m}^{-3}\right)$, limestone $\left(4-7 \mathrm{~kg} \mathrm{~m}^{-3}\right), \mathrm{pH} 6$ and humidification agent $100 \mathrm{ml} \mathrm{m}^{-3}$. Scion eggplants hybrids ('Classic F1' and 'Black Pearl F1') have been seeded at the same time but the rootstocks have been seeded at different dates. Lycopersicon genus rootstock ('Kaiser F1') has been seeded 5 days after the scion because they grow faster and Solanum genus rootstocks ('L1S', 'L23B' and 'Torpedo') have been seeded 20 days earlier than scions. Grafting has been made when both scion and rootstock plants have had stem diameters of $2-3 \mathrm{~mm}$ thick because grafting compatibility is dependent on similar values of thickness. The grafting method utilized in the experiment has been in simple copulation by performing a $45^{\circ}$ cut on the rootstock stem. A silicone sleeve has been applied over the cut; the scion was cut at $45^{\circ}$ and placed in the silicone sleeve, ensuring that the overlapping of the two cuts was perfect and also ensuring a close contact between scion and rootstock. After grafting the plants have been placed in callus tunnels for a period of 7 days at a temperature of 25 $26^{\circ} \mathrm{C}$, humidity of $98-99 \%$, in the absence of light for the first 3 days. After that they have been gradually exposed to light. Seedlings have been managed by following specific technology for producing vegetable seedlings until they were planted in the greenhouse. The number of seedlings studied was of 140 for each grafting combination, respectively 2 alveolar pallets of 70 plants each.

\section{Culture foundation and experimental design}

The culture was founded at the end of June in a $3.5 \mathrm{~m}$ Venlo greenhouse, without heating systems, with a metallic structure, covered in glass. Following soil preparation the fertilization was made with fertilizer complex 18:18:18 $(\mathrm{N}: \mathrm{P}: \mathrm{K}), 300 \mathrm{~kg} \mathrm{ha}^{-1}$, and then manure embedment, crumbling and levelling the soil have been performed. At grafted plants the planting was made on a flat surface in rows at $100 \mathrm{~cm}$ apart and at $55 \mathrm{~cm}$ in between plants per row, resulting in a density of 18,000 plants $\mathrm{ha}^{-1}$. At ungrafted plants the planting distance was of $100 \mathrm{~cm}$ in between rows and $40 \mathrm{~cm}$ in between plants, resulting in a density of 24,000 plants $\mathrm{ha}^{-1}$, thus having a lower vigour than the grafted ones.

During the vegetation time specific eggplant culture works in protected areas have been applied. The watering has been made through dropping, maintaining soil humidity at $80 \%$ from total water potential of field. The fertilization in phases has been made at every 10 days with complex fertilizer 15:15:15 (N:P:K) using 1 g per plant. The temperature was maintained at normal degrees $\left(25-30^{\circ} \mathrm{C}\right)$ through mechanical ventilation and shading. Fruit harvesting started in the first decade of September for 'Black Pearl F1' and in mid-September for 'Classic F1', continuing until the beginning of November.

\section{Plant sampling and biometrical determinations}

The percentage of successful grafted plants was obtained by comparing the number of healthy grafted seedlings to the total grafted plants for each grafting combination.

Biometric measurements concerning plant growth (i.e. height and number of leaves) and fructification (i.e. number of fruits per plant, average weight of fruits, total yield on the plant and per hectare) have been performed during the cropping period. Five randomly selected plants per plot were chosen at the beginning of the cropping season to determine the growth parameters.

\section{Fruit sampling and chemical analysis}

The analysis has been performed at Horting Bucharest using five fruits per variant when they were roughly $20 \mathrm{~cm}$ long and with high elasticity. The soluble dry substance has been determined using the WM-7 digital refractometer with a precision of $\pm 0.1 \%$ by ATAGO, with a drop of fruit juice and the result has been displayed on a graduated scale; after each sample the sample area has been washed with distilled water.

Total carbohydrates amount has been determined by the Bertrand method which consists of extracting the carbohydrates from the product with the help of water, purifying the plant extract and dosing reducing sugars in the purified extract (Gardner and Maclean, 1914; Alexe et al., 2012).

\section{Statistical analysis}

In what regards the production the results obtained have been statistically processed by the variant analysis method. The calculation has been made for 3 levels of significance: $0.05,0.01$ and 0.001 . The regression equation and measurement coefficient has been calculated for each hybrid to highlight the correlation between production and dry substance on one hand and between production and carbohydrates on the other. Moreover, the Duncan test has also been used to determine the 0.05 significance level.

\section{Results and Discussion}

\section{Plant development}

The grafting percentage has been observed to be between 95\% and 98\%, which showed a very good compatibility between scion and rootstock, both being from the same botanical family (Table 1). Plant compatibility at grafting has also been influenced by their diameter (McAvoy, 2005; Bogoescu et al., 2009; Doltu et al., 2013) which had values of $2-3 \mathrm{~mm}$ both at scion and rootstock, thus ensuring a perfect cover of the grafting area and a continuing vascularisation. The highest grafting percentage was recorded at the 'Classic F1' grafted on 'L23B' (98\%) and the lowest at 'Classic F1' grafted on 'L1S' (95\%); similar 
Table 1 . The percentage of plants resulted from grafting combinations (\%)

\begin{tabular}{ccc}
\hline Rootstock & Scion \\
\cline { 2 - 3 } & 'Classic F1' & 'Black Pearl F1' \\
\hline 'L1S' $K a i s e r ~ F 1 '$ & $95 \mathrm{~b}$ & $96 \mathrm{a}$ \\
'L23B' & $97 \mathrm{ab}$ & $97 \mathrm{a}$ \\
'Torpedo' & $98 \mathrm{a}$ & $97 \mathrm{a}$ \\
\hline Note: Different letters between variants denote significant differences (Duncan test, $\mathrm{p}<0.05)$. & $97 \mathrm{a}$ \\
\hline
\end{tabular}

grafting percentages were recorded at the 'Black Pear F1', 96\% grafted on 'L1S' and 97\% on the other rootstocks used.

The height of the eggplant plants has been influenced by the rootstocks, leading to a higher plant growth (Fig. 1). At the 'Classic F1' hybrid, the influence of ' $\mathrm{L} 23 \mathrm{~B}$ ' and 'Torpedo' rootstocks has been visible, the plants being 121.5 and $119.9 \mathrm{~cm}$ high in comparison to $93.2 \mathrm{~cm}$ at control. At the 'Black Pear F1' the results were similar but at this hybrid the influence of the Lycopersicon genus rootstock has impacted the height of plants. The height was $119.4 \mathrm{~cm}$ for the plants grafted on the 'Kaiser F1' rootstock and for the plants grafted on the 'Torpedo' rootstock of $120.1 \mathrm{~cm}$, compared to $89.1 \mathrm{~cm}$ at control.

The vigour of plants has also been determined through the number of leaves formed. It has been observed that at grafted plants at both hybrids studied the number of leaves was 2.5-3 times higher than at control, which demonstrates that eggplant grafting is a good method of producing planting material in order to obtain vigorous plants with high productive potential (Fig. 2).

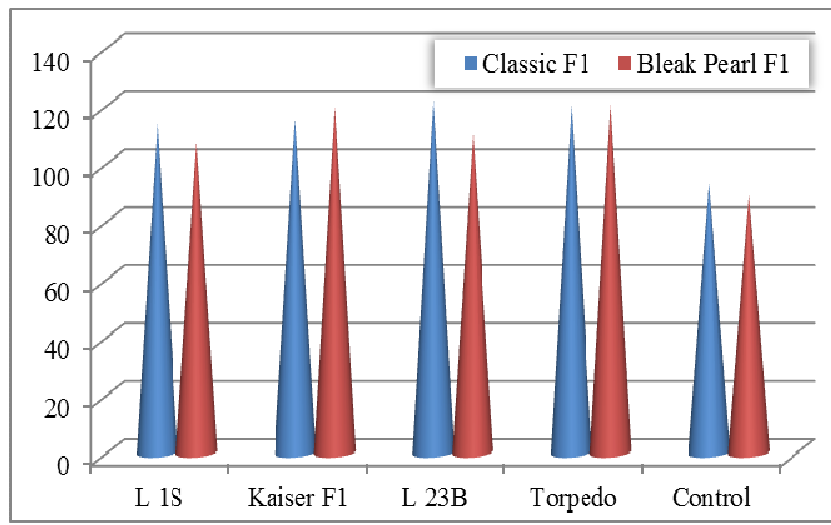

Fig. 1. Influence of rootstock on plant height $(\mathrm{cm})$

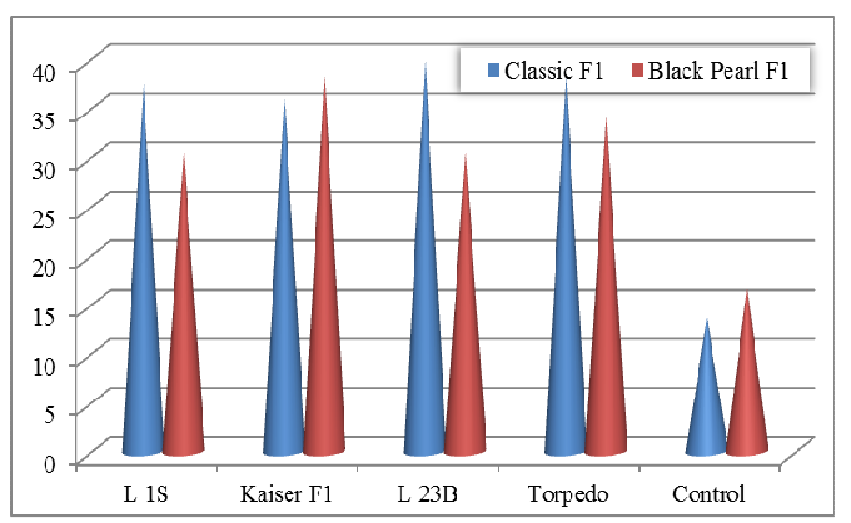

Fig. 1. Influence of rootstock on plant height $(\mathrm{cm})$

\section{Fructification}

The productive capacity of grafted plants studied through several indicators has been influenced by the rootstock used to produce seedlings. At the 'Classic F1' it has been noted that grafted plants formed more fruits than the control (Table 2). The 'Classic F1' grafted on 'L23B' and 'Torpedo' has formed over 10 fruit per plant and grafted on 'L1S' produced 9.76 fruits. Very good results have also been obtained at grafted plants on tomato rootstock 'Kaiser F1', with 9.49 fruits. Data from the specialty literature has showed that the cultivar 'Rima' grafted on the tomato rootstock formed 53\% and 60\% more fruits respectively in comparison to control in greenhouse and in field (Khah, 2005). Average fruit weight, $400 \mathrm{~g}$, has been higher for those obtained from plants grafted on 'Torpedo' and the smallest fruit average weight has been obtained from control, 375 g. Regarding production obtained on plant the rootstock used has had a large influence. Thus, the 'L23B' and 'Torpedo' rootstocks have determined the largest fruit production of over $4 \mathrm{~kg}$ of fruit per plant, followed by 'Kaiser F1' tomato rootstock with $3.78 \mathrm{~kg}$ per plant, compared to the same control on which fruit production per plant was $2.46 \mathrm{~kg}$. The absolute difference in plant production due to rootstock influence has been between $1.27 \mathrm{~kg}$ for 'L1S' and $1.80 \mathrm{~kg}$ for 'L23B' rootstock. Translated as a percentage, this difference has been between $51.66 \%$ for the 'LS1' rootstock and $73.58 \%$ for the 'L23B' rootstock. Eggplant production at hectare was higher at grafted plants than at control, ranging from 67.2 tons to 76.9 tons, compared to 59.1 tons at control. A small difference in production between the grafted and the control was due to a larger number of control at the surface unit (hectare). The highest yield per hectare, 30\%, has been obtained at grafted plants on the 'L23B' rootstock. Analyzing the results obtained, statistically, it has been observed that at both productionplant ${ }^{-1}$ and production $\mathrm{ha}^{-1}$ the rootstock has had a significant positive influence.

Plant grafting has stimulated the formation of a larger number of fruits. At 'Black Pearl F1' the difference was 26\% higher in comparison to control (Table 3). It has been observed that the largest number of fruits has been obtained at grafted plants on tomato rootstock 'Kaiser F1' with 9.92, followed by 'Torpedo' with 9.66 fruits, 'L23B' with 9.41 fruits and 'L1S' with 9.34 fruits, all compared to 6.67 fruit at control. The average fruit weight has slightly been influenced by the rootstock used, 'Kaiser F1' and 'Torpedo', resulting in an average weight of $417.59 \mathrm{~g}$ and respectively $414.34 \mathrm{~g}$. Fruit production per plant has greatly been influenced by the rootstock. The largest production was obtained at grafted plants on the tomato rootstock 'Kaiser F1', $4.15 \mathrm{~kg}$. Large production was also obtained at the grafted plants on the 'Torpedo' rootstock, $4.00 \mathrm{~kg}$, followed by the 'L1S' and 'L23B' rootstock with $3.62 \mathrm{~kg}$. From a 
Table 2. Productive capacity of 'Classic Fl' grafted on different rootstocks

\begin{tabular}{|c|c|c|c|c|c|c|c|c|}
\hline \multirow[t]{2}{*}{ Variant } & \multirow{2}{*}{$\begin{array}{l}\text { Number of } \\
\text { fruits per plant }\end{array}$} & \multirow{2}{*}{$\begin{array}{l}\text { Average fruit } \\
\text { weight } \\
\text { (g) }\end{array}$} & \multirow{2}{*}{$\begin{array}{c}\text { Average } \\
\text { production } \\
\left(\mathrm{kg} \mathrm{plant}^{-1}\right)\end{array}$} & \multicolumn{2}{|c|}{$\begin{array}{c}\text { Difference of production } \\
\text { per plant }\end{array}$} & \multirow{2}{*}{$\begin{array}{c}\text { Average } \\
\text { production } \\
\left(\mathrm{tha}^{-1}\right)\end{array}$} & \multicolumn{2}{|c|}{$\begin{array}{c}\text { Difference of production } \\
\text { per ha }\end{array}$} \\
\hline & & & & $\mathrm{kg}$ & $\%$ & & $\mathrm{t}$ & $\%$ \\
\hline V1 & $9.76 \mathrm{c}$ & $382.36 \mathrm{~b}$ & $3.73^{* * *}$ & 1.27 & 151.66 & $67.2^{* * *}$ & 8.1 & 113.71 \\
\hline V2 & $9.49 \mathrm{~d}$ & $398.62 \mathrm{a}$ & $3.78^{* * *}$ & 1.32 & 153.66 & $68.1^{* * *}$ & 9.0 & 115.23 \\
\hline V3 & $11.22 \mathrm{a}$ & $380.71 \mathrm{~b}$ & $4.27^{* * *}$ & 1.81 & 173.58 & $76.9^{* * *}$ & 17.6 & 130.12 \\
\hline V4 & $10.25 b$ & $400.04 a$ & $4.10^{* * *}$ & 1.64 & 166.67 & $73.8^{* * *}$ & 14.7 & 124.88 \\
\hline $\mathrm{V} 5(\mathrm{Ct})$ & $6.56 \mathrm{e}$ & $375.03 b$ & 2.46 & 0 & 100 & 59.1 & 0 & 100 \\
\hline LSD 5\% & & & 0.15 & & & 0.5 & & \\
\hline LSD 1\% & & & 0.23 & & & 0.7 & & \\
\hline LSD 0,1\% & & & 0.34 & & & 1.1 & & \\
\hline
\end{tabular}

Note: Different letters between variants denote significant differences (Duncan test, $\mathrm{p}<0.05$ ).

${ }^{*}=$ significant at $5 \% ;^{* *}=$ significant at $1 \% ;{ }^{* *}=$ significant at $0.1 \%$

Table 3. Productive capacity of 'Black Pear Fl' grafted on different rootstocks

\begin{tabular}{|c|c|c|c|c|c|c|c|c|}
\hline \multirow[t]{2}{*}{ Variant } & \multirow{2}{*}{$\begin{array}{c}\text { Number of fruits } \\
\text { per plant }\end{array}$} & \multirow{2}{*}{$\begin{array}{l}\text { Average fruit } \\
\text { weight } \\
\text { (g) }\end{array}$} & \multirow{2}{*}{$\begin{array}{c}\text { Average } \\
\text { production } \\
\left(\text { kg plant }^{-1}\right)\end{array}$} & \multicolumn{2}{|c|}{$\begin{array}{c}\text { Difference of } \\
\text { production per plant }\end{array}$} & \multirow{2}{*}{$\begin{array}{c}\text { Average } \\
\text { production } \\
\left(\mathrm{tha}^{-1}\right)\end{array}$} & \multicolumn{2}{|c|}{$\begin{array}{c}\text { Difference of production } \\
\text { per ha }\end{array}$} \\
\hline & & & & $\mathrm{kg}$ & $\%$ & & $t$ & $\%$ \\
\hline V6 & $9.34 \mathrm{c}$ & $387.87 \mathrm{~b}$ & $3.62^{* * *}$ & 1.03 & 139.77 & $65.2 \mathrm{~ns}$ & 3.0 & 104.83 \\
\hline V7 & $9.92 \mathrm{a}$ & $417.59 \mathrm{a}$ & $4.15^{* * *}$ & 1.56 & 160.24 & $74.7^{* * *}$ & 12.2 & 120.10 \\
\hline V 8 & $9.41 \mathrm{c}$ & $384.76 b c$ & $3.62^{* * *}$ & 1.03 & 139.77 & $65.2 \mathrm{~ns}$ & 3.0 & 104.83 \\
\hline V9 & $9.66 \mathrm{~b}$ & $414.34 \mathrm{ab}$ & $4.00^{* * *}$ & 1.41 & 154.44 & $72.0^{* *}$ & 9.8 & 115.76 \\
\hline $\mathrm{V} 10(\mathrm{Ct})$ & $6.67 \mathrm{~d}$ & $388.26 b$ & 2.59 & 0 & 100 & 62.2 & 0 & 100 \\
\hline LSD 5\% & & & 0.35 & & & 5.2 & & \\
\hline LSD 1\% & & & 0.51 & & & 7.6 & & \\
\hline LSD $0.1 \%$ & & & 0.77 & & & 11.4 & & \\
\hline
\end{tabular}

Note: Different letters between variants denote significant differences (Duncan test, $\mathrm{p}<0.05$ ).

${ }^{*}=$ significant at $5 \% ;^{* *}=$ significant at $1 \% ;{ }^{* * *}=$ significant at $0.1 \%$

statistical point of view, all the grafted variants were significantly positive. The absolute production difference per plant was between $1.03 \mathrm{~kg}$ at plants grafted on 'L1S' and 'L23B' and $1.56 \mathrm{~kg}$ at plants grafted on 'Kaiser F1' rootstock. Production difference per plant has highlighted the 'Kaiser F1' rootstock providing a $60.24 \%$ increase compared to the same control. The highest production yield obtained per hectare, $20 \%$, has been noted at plants grafted on the 'Kaiser F1' rootstock. From a statistical point of view the results were very positive for plants grafted on the 'Kaiser F1' rootstock and distinctly positive for grafted plants on the 'Torpedo' rootstock. The others were insignificant.

By comparing the production capacity of the two studied hybrids it has been showed that both hybrids have had very good results, the values obtained being similar (Table 4). The 'Classic F1' has had a slightly larger number of fruit per plan 9.45, which to a certain extent has influenced production per hectare. The 'Black Pearl F1' has been noted for a higher average fruit weight, $398.56 \mathrm{~g}$ and a slightly larger plant production, $3.59 \mathrm{~kg}$ respectively.

\section{Fruits quality}

The fruit content of soluble dry substance has had similar values at all variants (Table 5). It has been registered that fruits produced from grafted plants have had slightly higher dry matter content than those from control. However, according to some authors dry matter has decreased in grafted fruits (Cürük et al., 2005; Davis et al., 2008). At both hybrids, the 'Kaiser Fl' rootstock has directly influenced the content of the soluble dry substance. According to literature data (Gherghi et al., 2001) carbohydrate content has been slightly higher in fruits produced from grafted plants in comparison to the ones from ungrafted plants.

Analyzing the dependence between fruit production and soluble dry matter content, a small negative dependence was observed at both hybrids, $\mathrm{r}^{2}=0.414$ 'Classic F1' $\mathrm{r}^{2}=$ 0.389 hybrid on the 'Black Pear F1' (Figs. 3 and 4). Between fruit production per hectare and the total carbohydrate content the coefficient of determination was very weakly positive at 'Classic F1', $\mathrm{r}^{2}=0.064$ (Fig. 5), and negative, more pronounced, at 'Black Pear F1', $\mathrm{r}^{2}=0.508$ (Fig. 6).

Table 4. Hybrid influence on the production capacity at eggplants

\begin{tabular}{cccc}
\hline Variant & $\begin{array}{c}\text { Number of fruits } \\
\text { per plant }\end{array}$ & $\begin{array}{c}\text { Average fruit weight } \\
(\mathrm{g})\end{array}$ & $\begin{array}{c}\text { Average production } \\
\left(\mathrm{kg} \mathrm{plant}^{-1}\right)\end{array}$ \\
\hline 'Classic F1' & 9.45 & 387.35 & 3.52 \\
'Black Pearl F1' & 9.00 & 398.56 & 3.59 \\
\hline
\end{tabular}


Table 5. Content of dry substance and total carbohydrates amount at eggplant fruits

\begin{tabular}{cccc}
\hline \multirow{2}{*}{ Hybrid } & \multirow{2}{*}{ Variant } & Soluble dry substance & \multicolumn{2}{c}{ Total carbohydrates } \\
$(\%)$
\end{tabular}

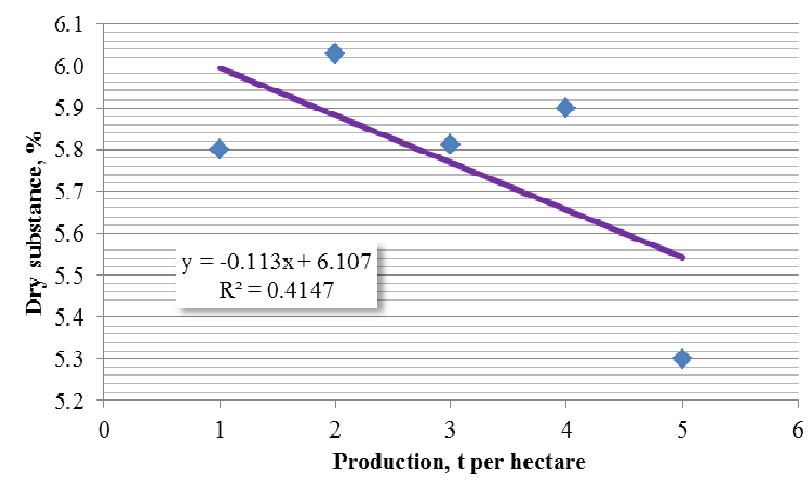

Fig. 3. The regression equation between production ( $t$ per hectare) and dry substance at 'Classic F1'

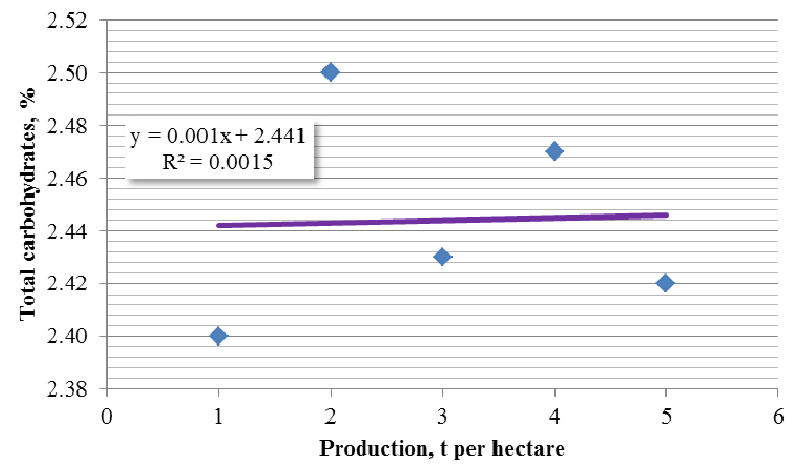

Fig. 5. The regression equation between production ( $t$ per hectare) and total carbohydrates at 'Classic F1'

\section{Conclusions}

Research on the production and cultivation of grafted eggplants has shown that this technique leads to producing plants with superior attributes compared to the ungrafted ones. Analyzing the influence of rootstock on the growth and fructification capacity of the grafted eggplants it has been found that all the rootstocks used have had a positive influence on plant growth. Grafted plants have exceeded the height of $1.0 \mathrm{~m}$ and the number of leaves has been 2.5 and 3.0 times larger than at control. In terms of average fruit weight there have been small differences between grafted and control, but at 'Classic F1' in all grafted variants the

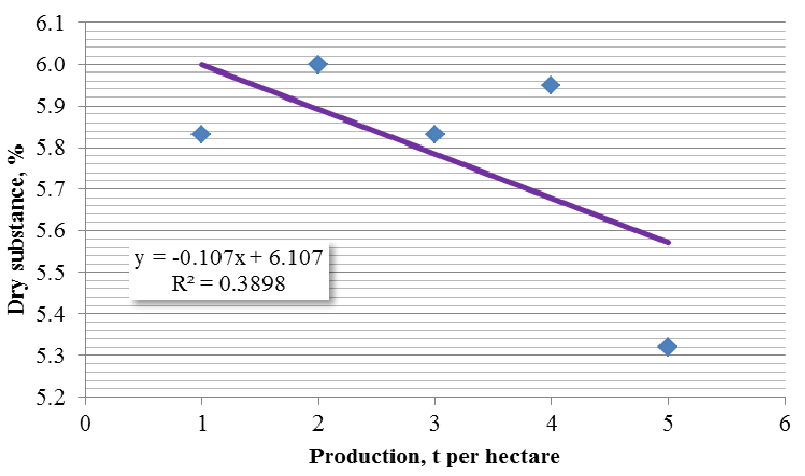

Fig. 4. The regression equation between production ( $t$ per hectare) and dry substance at 'Black Pear F1'

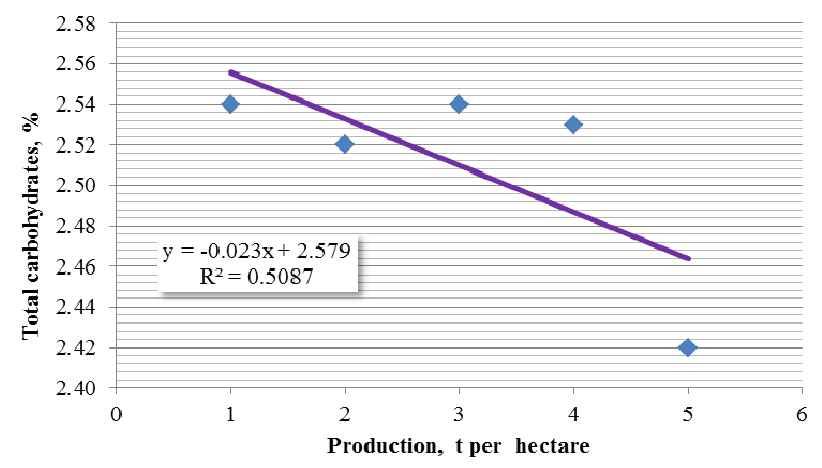

Fig. 6. The regression equation between production ( $t$ per hectare) and total carbohydrates at 'Black Pear F1'

fruits have been larger than at control. 'Black Pear F1' grafted on 'L1S' and 'L23B' has formed slightly smaller fruits. The 'Classic F1' grafted on 'L23 B' and 'Torpedo' eggplant rootstocks has had a higher fructification capacity compared to control. The 'Black Pear F1' grafted on 'Kaiser F1' and 'Torpedo' has had the highest fructification capacity. In terms of production per hectare it has been higher at grafted plants. The largest production increment per hectare was of 30\% for the 'Classic F1' grafted on 'L23B' and $20 \%$ for the 'Black Pear F1' grafted on 'Kaiser'. From the point of view of the biochemical composition of fruits there have been no differences between the grafted and control plants. 


\section{References}

Alexe C, Vintilă M, Popescu S, Dumitru LM, Lamureanu Gh, Chira $\mathrm{L}$ (2013). Researches on the influence of technological production and valorization factors on the commercial quality of cardinal peaches cultivar. Scientific papers Seria B LVII:13-18.

Assenza M (2004). Grafting tomatoes, an alternative to methyl bromide. Informatore Agrario 60(46):41-43.

Blestos FA, Olympios CM (2008). Rootstocks and grafting of tomatoes, peppers and eggplants for soil-borne disease resistance, improved yield and quality. The European Journal of Plant Science and Biotechnology 2(1):62-73.

Blestos FA, Thanassoulopoulos C, Roupakias D (2003). Effect of grafting on growth, yield, and Verticillium wilt of eggplant. HortScience 38:183-186.

Bogoescu M, Doltu M (2014). Cultivation of grafted eggplants (in Romanian). Ed Cerma Print.

Bogoescu M, Doltu M (2015). Effect of grafting eggplant (Solanum melongena L.) on its selected useful characters. Bulletin UASVM Horticulture Cluj-Napoca 72(2):313-317.

Bogoescu M, Doltu M, Iordache B, Tănasa N, Sora D, Mohora A (2010). Grafting watermelons crop, non chemical methyl bromide alternative in Romanian horticulture. Bulletin UASVM Horticulture Cluj-Napoca 67(1):224-229.

Bogoescu M, Doltu M, Moise D, Iordache B (2013). Research regarding the production of eggplant grafted seedlings by manual and semi-automatic grafting. Bulletin USAMV Cluj-Napoca 70(1):44-52.

Bogoescu M, Doltu M, Sora D, Iordache B (2008). Results on establishing the technology for obtaining the tomatoes grafted seedlings designed for greenhouses. Bulletin UASVM Horticulture Cluj-Napoca 65(1):147-152.

Bogoescu M, Doltu M, Sora D, Mohora A, Iordache B (2009). Results on establishing the technology for obtaining the watermelons grafted seedlings. Bulletin UASVM Horticulture Cluj-Napoca 66(1):397-403.

Collonnier C, Fock I, Kashyap V, Rotino GL, Daunay MC, Lian Y, ... Sihachakr D (2001). Applications of biotechnology in eggplant. Plant Cell, Tissue and Organ Culture, 65(2):91-107.

Çürük S, Dasgan HY, Mansuroglu S, Kurt S, Mazmanoglu M, Antakli O, Tarla G (2009). Grafted eggplant yield, quality and growth in infested soil with Verticillium dablia and Meloidogyne incognita. Pesquisa Agropecuária Brasileira 44(12):1673-1681.

Çürük S, Durga ÇC, Özdemir B, Kurt S, (2005). Comparisons of grafted biennial and conventional production systems for eggplant (Solanum melongena L.) varieties in a Mediterranean Region of Turkey. Asian Journal of Plant Sciences 2:117-122.

Davis AR, Perkins-Veazie P, Hassell R, King SR, Zhang X (2008). Grafting effects on vegetable quality. HortScience 43:1670-1672.

Doltu M, Bogoescu M, Sora D (2013). The influence of seed position on the emergence some rootstocks by Lagenaria siceraria. Bulletin UASVM Horticulture Cluj-Napoca 70(1):239-240.

Echevarria PH, Rodriguez A, Vivaracho SM, Vallejo AD (2004).
Influence of rootstocks and soil treatment on the yield and quality of greenhouse-grown cucumbers in Spain. Acta Horticulturae 663:403-408.

Elekcioglu IH, Ohnesorge B, Lung G, Uygun N (1994). Plant parasitic nematodes in the east Mediterranean region of Turkey. Nematologia Mediterranea 22(1):59-63.

Gardner AD, Maclean H (1914). A method for the estimation of sugar in blood with observations on some modern methods. Biochemical Journal 8(4):391-403.

Gherghi A, Burzo I, Bibicu M, Margineanu L, Badulescu L (2001). Biochemistry and physiology of vegetables and fruits (in Romanian). Ed Academiei Romane Bucuresti.

Haroldsen VM, Szczerba MW, Aktas H, Lopez-Baltazar J, Odias MJ, Chi-Ham CL, ... Powell TLA (2012). Mobility of transgenic nucleic acids and proteins within grafted rootstocks for agricultural improvement. Journal Frontiers in Plant Science 3:112.

Ioannou N (2001). Integrating soil solarization with grafting resistant rootstocks for management of soil-borne pathogen eggplant. Journal of Horticultural Science and Biotechnology 76:396-401.

Johnson SJ, Miles CA (2011). Effect of healing chamber design on the survival of grafted eggplant, tomato and watermelon. Hort Technology 21(6):752-758.

Kaushik P, Prohens J, Vilanova S, Gramazio P, Plazas M (2016). Phenotyping of eggplant wild relatives and interspecific hybrids with conventional and phenomics descriptors provides insight for their potential utilization in breeding. Frontiers in Plant Science 7:677.

Khah EM (2005). Effect of grafting on growth, performance and yield of aubergine (Solanum melongena L.) in the field and greenhouse. Journal of Food, Agriculture and Environment 3(3\&4):92-94.

King SR, Davis AR, Zhang X, Crosby K (2010). Genetics, breeding and selection of rootstocks for Solanaceae and Cucurbitaceae. Sciencia Horticulturae 127:106-111.

Kubota C (2008). Use of grafted seedlings for vegetable production in North America. Acta Horticulturae 770:21-28.

Lee JM (1994). Cultivation of grafted vegetables I: current status, grafting methods and benefits. HortScience 29(4):235-239.

Leonardi C, Giuffrida F (2006). Variation of plant growth and macronutrient uptake in grafted tomatoes and eggplants on three different rootstocks. European Journal of Horticultural Science 71(3):97-101.

McAvoy R (2005). Grafting techniques for greenhouse tomatoes. Greenhouse tomato Conference, University of Connecticut Cooperative Extension System. NESARE and UMass Extension.

Miguel A, Maroto JV, Bautista AS, Baixauli C, Cebolla V, Pascual B, Lopez-Galarza S, Guardiola JL (2004). The grafting of triploid watermelon is an advantageous alternative to soil fumigation. Scientia Horticulturae 103:9-17.

Moncada A, Miceli A, Vetrano F, Mineo V, Planeta D, D’Anna F (2013). Effect of Grafting on yield and quality of eggplant (Solanum melongena L.). Scientia Horticulturae 149:108-114.

Na Liu, Baoli Zhou, Xin Zhao, Bo Lu, Yixiu Li, Jing Hao (2009). 
480

Grafting eggplant onto tomato rootstock to suppress Verticillium dabliae infection: the effect of root exudates. HortScience 44:2058-2062.

Petran AJ (2013). Interspecific grafting of tomato (Solanum lycopersicum) onto wild eggplant (Solanum torvum) for increased environmental tolerances. $\mathrm{PhD}$ Thesis University of Minnesota.

Romano D, Paratore A (2001). Effects of grafting on tomato and eggplant. Acta Horticulture 559:149-154.

Tarchoun N, Boughalleb N, Mbarki AEL (2005). Agronomic evaluation of nine cucurbit rootstocks and watermelon grafted (Citrullus lanatus T.). Revue del'INAT 20:125-140.

Vînătoru C, Teodorescu E, Zamfir B (2013). New H1 Buzau F1 hybrid of eggplant obtained at VRDS Buzau. Scientific papers USAMV Bucureşti Seria B LVII:245-248.
Yassin H, Hussen S (2015). Review on role of grafting on yield and quality of selected fruit vegetables. Global Journal of Science Frontier Research D: Agriculture and Veterinary 15(1).

Yetisir H, Kurt S, Sari N, Tok FM (2007). Rootstock potential of Turkish Lagenaria siceraria germplasm for watermelon: Plant growth, graft compatibility, and resistance to Fusarium. Turkish Journal Agriculture and Forestry 31:381-388.

Yetisir H, Sari N (2003). Effect of different rootstock on plant growth yield and quality of Watermelon. Australian Journal of Experimental Agriculture 43:1269-1274. 